\title{
PENGARUH MEDIA AUDIO VISUAL TERHADAP MOTIVASI BELAJAR IPA SISWA KELAS V SDN KAPOPO
}

\author{
Azizah $^{1}$, Nurul Fatimah ${ }^{2}$ \\ ${ }^{1}$ Universitas Tadulako \\ Email: azizahrosnadi@gmail.com \\ 2 Universitas Tadulako \\ Email: nurulfatimahadam04@gmail.com
}

\begin{abstract}
Abstrak
Penelitian ini bertujuan untuk mengetahui pengaruh Media Audio Visual terhadap motivasi belajar IPA siswa. Jenis penelitian adalah quasi eksperimen dengan desain One Group pretest-posttest design. Penelitian ini dilaksanakan di kelas V SDN Kapopo. Instrumen yang digunakan dalam penelitian ini yaitu angket untuk mengukur motivasi belajar IPA siswa. Analisis data terdiri dari Uji validitas, reliabilitas, uji normalitas dan Uji-t digunakan untuk menguji hipotesis penelitian berbantuan program SPSS 25. Hasil penelitian menunjukkan bahwa media Audio Visual berpengaruh terhadap motivasi belajar IPA siswa. Hal tersebut dilihat dari perolehan nilai sig $<\alpha$ yaitu $0,000<0,05$ pada taraf signifikansi $5 \%$ sehingga $\mathrm{H}_{\circ}$ ditolak dan $\mathrm{H}_{a}$ diterima. Sehingga dapat disimpulkan bahwa penggunaan media audio visual berpengaruh terhadap motivasi belajar IPA siswa kelas V SDN Kapopo.
\end{abstract}

Kata kunci: Media Audio Visual, Motivasi Belajar

\begin{abstract}
This study aims to determine the effect of Audio Visual Media on students' motivation to learn science. This type of research is a quasi-experimental design with One Group pretest-posttest design. This research was conducted in class $V$ $S D N$ Kapopo. The instrument used in this research is a questionnaire to measure students' motivation to learn science. Data analysis consisted of validity, reliability, normality test and t-test used to test the research hypothesis assisted by the SPSS 25 program. The results showed that Audio Visual media had an effect on students' motivation to learn science. This can be seen from the acquisition of the value of sig $<$ which is $0.000<0.05$ at a significance level of $5 \%$ so that $H_{0}$ is rejected and $H_{a}$ is accepted. So it can be concluded that the use of audio-visual media has an effect on the motivation to learn science for fifth graders at SDN Kapopo.
\end{abstract}

Keywords: Audio Visual Media, Learning Motivation

\section{Pendahuluan}

Pendidikan sangat berperan penting dalam mempersiapkan sumber daya manusia yang berkualitas. Pendidikan sebagai salah satu tempat untuk meningkatkan kualitas sumber daya manusia yang dilaksanakan melalui pembelajaran. Pembelajaran diharapkan mampu mendewasakan setiap individu melalui proses dan pelatihan. Sebagaimana menurut Kamus Besar Bahasa Indonesia bahwa Pendidikan merupakan proses pengubahan sikap dan perilaku seseorang atau sekelompok orang dalam usaha mendewasakan manusia melalui upaya pengajaran dan pelatihan. Sehingga melalui Pendidikan dapat menghasilkan sumber daya manusia yang berkualitas dan mampu mengembangkan perilaku seseorang menuju kearah pendewasaan.

Perkembangan Pendidikan saat ini sudah terkena dampak oleh adanya perkembangan teknologi. Untuk mengimbangi dari dampak teknologi ini 
diharapkan pendidik mampu mengimbangi perkembangan tersebut dengan cara memberikan pembelajaran yang menarik, inspiratif, menyenangkan, menantang, memotivasi peserta didik untuk berpartisipasi aktif dalam pembelajaran, serta memberi ruang untuk peserta didik dalam mengembangkan kreativitas, bakat, dan minat peserta didik itu sendiri. Untuk menciptakan hal tersebut, guru harus pandai berinovasi dalam penggunaan metode, model, ataupun media pembelajaran, sehingga dapat membantu memotivasi siswa dalam pembelajaran, khususnya pada pembelajaran IImu Pengetahuan Alam (IPA). Mahnun, (2012) menyebutkan bahwa media merupakan sarana penyalur pesan atau informasi belajar yang hendak disampaikan oleh sumber pesan kepada sasaran atau penerima pesan tersebut. Sebagaimana menurut Azizah \& Winarti, (2016) siswa juga harus mampu melakukan berbagai keterampilan proses sains sebagai konsekuensi hakikat sains. Keterampilan proses tersebut akan mengantar siswa memperoleh produk sains berupa pengetahuan.

Menurut (Azizah, Puji Winarti, 2020) IPA merupakan pelajaran yang sangat penting diajarkan di sekolah karena dapat melatih siswa untuk bersikap ilmiah serta berpikir kreatif dan objektif. Pembelajaran IPA dapat membantu dalam memahami dan mengetahui alam semesta serta kehidupan makhluk hidup disekitar kita. Susanto (2013) mengatakan bahwa IPA adalah usaha manusia dalam memahami alam semesta melalui pengamatan yang tepat pada sasaran, serta menggunakan prosedur dan dijelaskan dengan penalaran sehingga mendapatkan suatu kesimpulan. Pembelajaran IPA adalah pembelajaran yang menekankan pada pemberian pengalaman secara langsung baik menggunakan eksperimen maupun observasi ataupun yang lainnya, sehingga data yang didapatkan benarbenar valid dan bisa dipertanggungjawabkan (Azizah \& Winarti, 2016).

Ditingkat SD/MI diharapkan ada penekanan pembelajaran Salingtemas (Sains, lingkungan, teknologi, dan masyarakat) yang diarahkan pada pengalaman belajar untuk merancang dan membuat suatu karya melalui penerapan konsep IPA dan kompetensi bekerja ilmiah secara bijaksana (BNSP, 2006). Dalam mempelajari materi-materi IPA yang masih bersifat abstrak dan tidak disertakan dengan hal-hal yang dapat membantu peserta didik dalam memahami materi, maka hasil yang akan dicapai oleh peserta didik dalam pembelajaran IPA berupa hafalan materi saja. Hendaknya dalam sebuah pembelajaran IPA agar dapat menjadi lebih bermakna pembelajaran dapat dilakukan dengan bantuan sebuah media pembelajaran, agar peserta didik lebih termotivasi dan bersemangat untuk mengikuti proses pembelajaran. Media pembelajaran merupakan alat dan Teknik yang digunakan sebagai perantara komunikasi antara seorang guru dan siswa (Azizah, Puji Winarti, 2020). Indaryati, (2015) mengatakan bahwa media pembelajaran adalah salah satu faktor utama yang dapat mempengaruhi hasil belajar siswa, karena melalui medialah pesan 
pembelajaran dapat disampaikan sesuai dengan tujuan pembelajaran tersebut.

Media pembelajaran merupakan bagian yang tak terpisahkan dari kegiatan belajar mengajar di sekolah. Pemanfaatan media pembelajaran merupakan upaya kreatif dan sistematis untuk menciptakan pengalaman yang dapat membelajarkan serta memotivasi siswa dalam mengembangkan pengetahuannya. Media yang baik juga akan mengaktifkan siswa dalam memberikan tanggapan, umpan balik, dan juga mendorong untuk melaksanakan praktek-praktek dengan benar (Azizah, 2018). Sedangkan menurut Syastra, (2015) bahwa media pembelajaran adalah segala sesuatu baik berupa fisik maupun teknis dalam proses pembelajaran yang dapat membantu guru untuk mempermudah dalam menyampaikan materi pelajaran kepada siswa sehingga memudahkan pencapaian tujuan pembelajaran yang telah dirumuskan. Selanjutnya Purwono, (2014) menjelaskan bahwa media pembelajaran memiliki peranan penting dalam menunjang kualitas proses belajar mengajar. Penggunaan media pembelajaran mempunyai tujuan memberikan motivasi kepada peserta didik serta merangsang siswa mengingat apa yang sudah dipelajari selain memberikan rangsangan belajar baru (Azizah, 2018).

Motivasi merupakan salah satu faktor yang mempengaruhi peserta didik dalam belajar. Schunk, D. H., Pintrinch, P.R \& Meece, (2010) mengatakan bahwa motivasi memiliki hubungan dengan kemampuan belajar. Seseorang akan mencapai tujuan yang diinginkannya apabila seseorang itu mempunyai motivasi yang kuat dalam dirinya. Sehingga pada proses pembelajaran dengan adanya motivasi belajar dapat menghasilkan suatu keinginan untuk berhasil, dorongan dan kebutuhan dalam belajar dan antusias dalam belajar pada diri peserta didik. Inilah sebabnya motivasi sangat berpengaruh pada saat proses pembelajaran karena melalui motivasi peserta didik mampu mencapai tujuan yang ingin dicapainya.

Berdasarkan hasil observasi dan wawancara yang dilakukan oleh peneliti di SDN Kapopo Kecamatan Sigi Biromaru Kabupaten Sigi bersama guru wali kelas $\mathrm{V}$ mengenai masalah-masalah yang dihadapi guru dalam proses belajar mengajar salah satunya yaitu bahwa kurangnya pemahaman siswa pada materi yang diberikan sehingga menyebabkan nilai hasil belajar menurun. Banyak peserta didik yang tidak aktif dalam kegiatan belajar mengajar dan hanya sibuk bermain sendiri, saling berbicara Bersama temannya satu sama lain dan menganggu temannya tanpa memperhatikan penjelasan dari guru dan itu dilakukan pada saat pembelajaran IPA. Hal tersebut terjadi dalam proses pembelajaran disebabkan karena motivasi belajar siswa yang kurang Jika melakukan pembelajaran dengan motivasi yang kurang maka akan memperoleh hasil belajar yang kurang juga.

Pada proses pembelajaran guru hanya menggunakan metode ceramah dan beberapa alat peraga yang ada di sekolah. Guru kurang memberikan ruang untuk siswa dapat bereksperimen sehingga motivasi siswa untuk belajar sangat menurun. Kurangnya motivasi 
siswa terhadap pembelajaran IPA berdampak pada hasil belajar siswa sehingga nilai yang diperoleh sebagian siswa masih dibawah Kriteria Ketuntasan Minimal (KKM).

Melihat kondisi saat ini, dimana pembelajaran yang dilakukan secara daring maupun luring karena adanya pandemi COVID-19 yang tidak memungkinkan untuk tatap muka karena dapat beresiko pada kesehatan masyarakat sehingga guru dituntut untuk melakukan proses pembelajaran secara daring/luring.

Sekarang ini pembelajaran dilakukan guru yaitu pembelajaran yang berupa pemberian tugas. Tugas yang dikerjakan terdapat dalam buku paket siswa. Guru memberi kesempatan kepada siswa untuk membawa buku paket tersebut ke rumah masing-masing. Setelah dilakukan observasi, dengan adanya pemberian tugas peserta didik sangat merasa bosan dan motivasi belajarnya menurun dengan hanya menggunakan buku sebagai bahan bacaan apalagi dalam pembelajaran IPA. Melihat kondisi tersebut, maka salah satu solusi yang dapat dilakukan yaitu dengan menggunakan media pembelajaran yang berupa media audio visual yang nantinya media tersebut dapat berupa video pembelajaran tentang materi IPA.

Berdasarkan masalah tersebut, peneliti sangat tertarik untuk melakukan penelitian eksperimen tentang pengaruh media audio visual terhadap motivasi belajar siswa. Karena dengan adanya kebijakan pemerintah yang memilih untuk tidak melakukan kegiatan belajar mengajar di sekolah melainkan melakukan pembelajaran melalui pembelajaran daring/luring, sehingga media pembelajaran yang berupa media audio visual sangat membantu peserta didik dalam memahami materi dan peserta didik juga tidak bosan karena dalam media audio visual terdapat gambar-gambar yang menarik dan dapat merangsang motivasi siswa untuk memahami materi yang diberikan. Untuk itu peneliti tertarik untuk melakukan penelitian dengan judul "Pengaruh media audio visual terhadap motivasi belajar IPA siswa kelas V SDN Kapopo".

Berdasarkan latar belakang yang telah dikemukakan, dapat dirumuskan masalah dalam penelitian ini yaitu: "Apakah ada pengaruh media audio visual terhadap motivasi belajar IPA siswa kelas V SDN Kapopo?" Penelitian ini dilakukan dengan tujuan untuk mengetahui apakah ada pengaruh media audio visual terhadap motivasi belajar IPA siswa kelas V SDN Kapopo.

\section{Metode Penelitian}

Metode yang digunakan dalam penelitian ini adalah metode Preeksperimen. Desain penelitian yang digunakan dalam penelitian ini adalah one group pretest posttest design. Penelitian ini dilaksanakan di kelas $\mathrm{V}$ SDN Kapopo yang bertempat di Desa Ngatabaru Kecamatan Sigi Biromaru Kabupaten Sigi. Penelitian ini dilaksanakan pada bulan Oktober 2020. Sampel penelitian yang digunakan dalam penelitian ini yaitu seluruh kelas V SDN Kapopo Tahun Ajaran 2020/2021. Jenis data yang digunakan dalam penelitian ini adalah data kuantitatif dan data kualitatif sedangkan sumber data dalam penelitian ini berupa dua jenis sumber data yaitu data primer dan data sekunder. Dalam penelitian ini alat pengumpulan data 
yang digunakan adalah wawancara dan angket (kuesioner).

Sugiyono, (2015) menjelaskan mengenai pengertian dari variabel yaitu: "Variabel penelitian adalah suatu atribut atau sifat atau nilai dari orang, atau kegiatan yang mempunyai variasi tertentu yang ditetapkan oleh peneliti untuk dipelajari dan ditarik kesimpulannya". Menurut Sugiono, berdasarkan hubungan antara satu variabel dengan variabel lain, maka variabel dalam penelitian ini adalah variabel bebas (Independent Variable) dan variabel terikat (Dependent Variable). Dalam penelitian ini terdapat variabel $(X)$ yaitu penggunaan media audio visual dan variabel $(\mathrm{Y})$ yaitu motivasi belajar siswa. Dimana kita melihat hubungan kedua variabel ini dari pengaruh penggunaan media audio visual terhadap motivasi belajar siswa kelas V SDN Kapopo. Teknik analisis data yang digunakan dalam penelitian ini meliputi Uji-t dengan berbantuan SPSS versi 25.

\section{Hasil dan Pembahasan}

Pada Penelitian ini merupakan penelitian kuantitaif dengan desain penelitian one group pretest posttest design. Sebelum siswa diberikan perlakuan dengan pembelajaran menggunakan media audio visual, terlebih dahulu siswa diberikan angket pretest tentang motivasi belajar siswa. Setelah itu diberikan perlakuan dengan menggunakan media audio visual dalam proses pembelajaran. Setelah perlakuan diberikan kemudian siswa diberikan lagi posttest tentang motivasi belajar siswa. Adapun hasil pretest dan posttest siswa kelas V SDN Kapopo dapat dilihat pada tabel 1 berikut.

Tabel 1. Nilai pretest dan posttest motivasi belajar siswa

\begin{tabular}{|c|c|c|}
\hline Uraian & Tes Awal (Pretest) & Tes Akhir (Posttest) \\
\hline Subjek & 11 & 11 \\
\hline Nilai Terendah & 83 & 88 \\
\hline Nilai Tertinggi & 93 & 98 \\
\hline Nilai Rata-rata & 88,18 & 93,86 \\
\hline Standar Deviasi & 3,371 & 3,233 \\
\hline
\end{tabular}

Berdasarkan hasil analisis pada tabel di atas didapatkan hasil pretest siswa kelas V SDN Kapopo dengan nilai terendah 83 dan nilai tertinggi 93. Sehingga diperoleh nilai rata-rata 88,18 dan standar deviasi 3,233. Sedangkan hasil posttest siswa kelas V SDN Kapopo dengan nilai terendah 88 dan nilai tertinggi 98 . Sehingga diperoleh nilai rata-rata yaitu 93,86 dan standar deviasi 3,233 .
Selanjutnya, uji normalitas angket pretest digunakan untuk mengetahui item angket yang akan diuji cobakan berdistribusi normal atau tidak. Setelah dilakukan uji reliabilitas kemudian dilakukan uji normalitas pretest dengan berbantuan SPSS 25 Shapiro Wilk. Pretest diberikan diawal pembelajaran untuk mengetahui kemampuan awal siswa. Data hasil analisis dapat dilihat pada tabel berikut. 
Tabel 2. Hasil analisis normalitas data pretest dan postest

\begin{tabular}{|c|c|c|c|}
\hline \multirow{2}{*}{ Pretest } & \multicolumn{3}{|c|}{ Shapiro Wilk } \\
\cline { 2 - 4 } & Statistic & $D f$ & Sig \\
\cline { 2 - 4 } &, 899 & 11 &, 180 \\
\hline Posttest &, 909 & 11 &, 238 \\
\hline
\end{tabular}

Berdasarkan tabel di atas hasil analisis tersebut adalah nilai signifikansi Shapiro Wilk pada pretest adalah 0,180 $>$ 0,05 dan posttest sebesar 0,238 sehingga dapat disimpulkan bahwa data berdistribusi normal. Karena data berdistribusi normal maka analisis dapat dilanjutkan.

Pengujian Hipotesis penelitian ini menggunakan Uji Signifikansi (Uji-t). Uji signifikansi dilakukan untuk mengetahu rata-rata skor motivasi belajar siswa pada kelas eksperimen lebih besar setelah adanya perlakuan. Perhitungan uji perbedaan dua rata-rata dilakukan dengan uji Paired Samples Test dengan menggunakan program SPSS versi 25. Data hasil uji-t berbantuan SPSS 25 didapatkan bahwa nilai signifikansi dengan taraf $5 \%$ yaitu sebesar $0,000<$ 0,05 maka $\mathrm{H}_{\mathrm{o}}$ ditolak, artinya bahwa terdapat adanya pengaruh media audio visual terhadap motivasi belajar IPA siswa kelas V SDN Kapopo.

Hasil penelitian membuktikan adanya peningkatan motivasi belajar siswa dalam menggunakan media audio visual. Hal ini dapat dilihat dari hasil analisis data akhir motivasi belajar siswa. Sebelum diberikan perlakuan penggunaan media audio visual diperoleh nilai motivasi belajar siswa sebesar 88,18. Setelah dilakukan perlakuan penggunaan media audio visual diperoleh nilai hasil motivasi belajar siswa sebesar 93,86. Berdasarkan hasil analisis tersebut menunjukkan bahwa nilai rata-rata motivasi belajar IPA siswa kelas $\mathrm{V}$ setelah dilakukan posttest lebih tinggi dari hasil pretest atau terdapat perbedaan yang signifikan. Selanjutnya hal tersebut didukung dari hasil uji signifikansi (Uji-t). Pada uji-t diperoleh nilai Sig $(2$-tailed $)=0,000$. Nilai Sig $=$ $0,000<$ taraf signifikansi $=0,05$ maka $\mathrm{H}_{\mathrm{o}}$ ditolak dan $\mathrm{Ha}$ diterima pada taraf kepercayaan 95\%. Setelah dilakukan pembuktian dua variabel dengan menggunakan uji-t maka dapat disimpulkan bahwa adanya pengaruh media audio visual terhadap motivasi belajar IPA siswa kelas V SDN Kapopo.

Penggunaan media audio visual dalam pembelajaran dapat memberikan pengaruh terhadap motivasi belajar siswa pada mata pelajaran IPA kelas $V$ SDN Kapopo. Dalam kondisi pandemic sekarang ini media audio visual sangat membantu siswa dalam memahami materi di rumah dan membuat siswa tidak bosan hanya dengan menggunakan buku saja. Hal ini sejalan dengan penelitian yang dilakukan oleh Housand, B.C \& Housand, (2012) yang mengatakan bahwa dengan adanya teknologi berupa media video dapat meningkatkan motivasi. Media video merupakan teknologi yang dapat membuat peserta didik termotivasi dalam belajar. Hal ini juga dipertegas oleh Odera, (2011) mengatakan bahwa penggunaan media Pendidikan dan teknologi dianggap dapat memberikan motivasi kepada siswa selama proses pembelajaran berlangsung. Hal yang 
sama juga diungkapkan oleh Star, J.R., A.J., Taylor, M.W., Durkin, K., Dede, C \& Chao, (2014) bahwa salah satu cara untuk memicu motivasi, minat dan membangun rasa kompetensi dalam pembelajaran matematika dan sains adalah melalui penggunaan berbagai media teknologi berupa media audio visual.

Melalui media audio visual atau media video yang diberikan pada pembelajaran IPA dapat memicu motivasi peserta didik sehingga dapat membangun rasa kompetensi bagi peserta didik. Media video yang digunakan dalam pembelajaran mampu memberikan rangsangan belajar yang lebih baik bagi peserta didik karena dengan media video peserta didik dapat mengingat materi pembelajaran lebih lama. Penelitian Jacobs dan Schade dalam Munir, (2012) membuktikan hal ini dengan mengungkapkan bahwa daya ingat siswa yang hanya membaca saja memberikan presentase terendah, yaitu $1 \%$. Daya ingat siswa dapat ditingkatkan hingga 25\%-30\% dengan bantuan media lain seperti televisi. Daya ingat siswa makin meningkat hingga $60 \%$ dengan penggunaan multi media. Media video hampir sama dengan multi media karena dapat menampilkan gambar, teks, suara dan animasi dalam sebuah tampilan yang menarik.

Pembelajaran dengan menggunakan media audio visual atau video dapat mengatasi kendala atau kesulitan yang terjadi dalam proses pembelajaran IPA.
Proses pembelajaran yang baik akan mendukung keberhasilan dalam suatu kegiatan pembelajaran. Atas dasar inilah peneliti melakukan suatu eksperimen dengan menggunakan media audio visual dalam pembelajaran IPA yang belum pernah dilakukan sebelumnya. Pembelajaran dengan menggunakan media audio visual ini bertujuan untuk mengatasi persoalan dalam pembalajar IPA di SDN Kapopo yang cenderung monoton karena pembelajaran yang diberikan oleh guru dinilai kurang membuat peserta didik aktif dan kreatif.

\section{Kesimpulan}

Berdasarkan hasil penelitian dan pembahasan, dapat disimpulkan bahwa media audio visual berpengaruh terhadap motivasi belajar IPA siswa kelas V SDN Kapopo. Hal ini dapat dilihat dari rata-rata nilai pretest adalah 88,18 dan nilai Posttest yang menggunakan media audio visual adalah 93,86. Hasil Uji-t diperoleh nilai signifikansi $0,000<0,05$ maka $\mathrm{H}_{\mathrm{o}}$ ditolak dan Ha diterima.

Berdasarkan hasil penelitian, diharapkan guru dapat menggunakan media audio visual dalam proses pembelajaran sesuai dengan materi yang diajarkan guna meningkatkan motivasi belajar siswa. Selain itu, pihak sekolah diharapkan dapat menyiapkan dan melengkapi fasilitas yang dapat digunakan dalam proses pembelajaran. 


\section{Daftar Pustaka}

Azizah, Puji Winarti, N. K. S. (2020). Pengembangan Modul Praktikum Serli (Discovery Learning) untuk Pembelajaran Sains di Sekolah Dasar. Jurnal Profesi Pedidikan Dasar, 7 No 1(doi.org/10.23917/ppd.v1i1.10817).

Azizah. (2018). Pengembangan Modul Pratikum Dilan (Discovery Learning) untuk Pembelajaran Sains di kelas V Sekolah Dasar. 2(2).

Azizah, \& Winarti, P. (2016). Pengaruh Metode Guided Discovery Terhadap Hasil Belajar Ipa Siswa Kelas Iv Sdn Gedanganak 01 Kecamatan Ungaran Timur Kabupaten Semarang. Jurnal Profesi Pendidikan Dasar, 3(1), 1-9. https://doi.org/10.23917/ppd.v3i1.2714

BNSP. (2006). Standar ISi. BNSP.

Housand, B.C \& Housand, A. . (2012). The role of technology in gifted students' motivation. Psychology in the Schools, 49 (7). http://eresources.pnri.go.id:2057/docview/1509047421?pq-origsite=summon.

Indaryati, J. (2015). Pengembangan Media Komik Pembelajaran matematika meningkatkan motivasi dan prestasi belajar siswa kelas V. Jurnal Prima Edukasia, 3.

Mahnun, N. (2012). Media Pembelajaran. Pemikiran, 37 No 1, 27.

Munir. (2012). Multimedia konsep dan aplikasi dalam pendidikan. Alfabeta.

Odera, F. Y. (2011). Motivation: the most ignored factor in clasroom instruction in kenyan secondary school. Internasional Journal of Science and Technology, http://eresources.pnri.go.id:2075/media/pq/classic/doc/1798979291/fmt/pi/rep/N ONE?hl=\&cit\%, 1, 283-288.

Purwono, J. (2014). Penggunaan Media Audio Visual pada mata pelajaran IImu Pengetahuan Alam. Jurnal Teknologi Pendidikan Dan Pembelajaran, 3 No 2, 127.

Schunk, D. H., Pintrinch, P.R \& Meece, J. . (2010). Motivation in Education:theory, research, and applications. Colombus : Pearson Education.

Star, J.R., A.J., Taylor, M.W., Durkin, K., Dede, C \& Chao, T. (2014). Studying technology-based strategies for enhancing motivation in mathematics. Internasional Journal of STEM Education, http://web.a.ebscohost.com/ehost/pdfviewer/pdfviewer?sid=7f32fb47-b37e410d-a9c4ce9583b34c84\%40sessionmgr4004\& vi=1\& hid=4206, 1-7.

Sugiyono. (2015). metode penelitian pendekatan kualitatif, kuantitatif dan $R \& D$. Alfabeta. 
Susanto, A. (2013). Teori belajar dan Pembelajaran disekolah dasar. Kencana Prenada Media Group.

Syastra, S. . dan M. T. (2015). Pemanfaatan Media Pembelajaran berbasis teknologi informasi. Jurnal CBIS, 3 No 2, 79. 